\title{
ANALISIS PENGARUH EKSPOR IMPOR TERHADAP NILAI TUKAR USD DAN SGD
}

\author{
Kurniawan Sabtiadi, Dwi Kartikasari \\ Prodi Administrasi Bisnis Terapan \\ Politeknik Negeri Batam \\ *Corresponding author. Tel/HP: 0821-6993-7754; \\ Email : Wawanamstrong8@gmail.com
}

\begin{abstract}
Abstrak
Penelitian ini bertujuan untuk mengetahui pengaruh dari: (1) ekpor nasional terhadap nilai tukar usd dan sgd, (2) impor nasional terhadap nilai tukar usd dan sgd, (3) ekspor kota Batam terhadap nilai tukar usd dan sgd, dan (4) impor kota Batam terhadap nilai tukar usd dan sgd. Metode kuantitatif digunakan dalam penelitian ini dengan sumber data berasal dari data sekunder dan menggunakan metode analisis regresi linier berganda. Pemilihan metode analisis regresi linier berganda dianggap tepat sebagai alat untuk mengolah data berupa time series seperti data yang digunakan dalam penelitian ini. Hasil penelitian menunjukkan bahwa (1) ekpor nasional memiliki pengaruh terhadap nilai tukar usd dan sgd, (2) impor nasional memiliki pengaruh terhadap nilai tukar usd dan sgd, (3) ekspor kota Batam memiliki pengaruh terhadap nilai tukar usd dan sgd, (4) ekspor impor nasional dan kota Batam, secara bersama sama memiliki pengaruh terhadap nilai tukar usd dan sgd.
\end{abstract}

Kata Kunci: Analisis regresi linier berganda, ekspor, impor, nilai tuka

\section{PENDAHULUAN}

Kegiatan impor adalah upaya seorang pengusaha untuk memenuhi kebutuhannya atas suatu barang yang kurang tersedia di dalam negeri, sehingga terpaksa membelinya dari negara lain, serta membayarnya dengan valuta asing (Amir, 2008). Demi kelancaran terjadinya transaksi perdagangan internasional yang efisien maka uang ditetapkan sebagai alat pembayarannya. Perbedaan nilai mata uang yang digunakan oleh setiap negara yang melakukan perdagangan internasional menimbulkan perbedaan nilai tukar atau biasa disebut dengan kurs. Seperti yang kita ketahui, perdagangan internasional menggunakan mata uang USD atau SGD sebagai nilai dari sebuah barang yang akan di ekspor maupun impor. Sebagai negara berkembang, Indonesia harus meningkatkan sektor industri agar tidak selalu bergantung kepada negara lain. Indonesia tidak dapat mengandalkan sumber daya alam terus menerus karena sumber daya alam sifatnya terbatas. Oleh sebab itu, ketika sumber daya di Indonesia sudah sangat terbatas, maka Indonesia akan mencarinya ke negara lain. Negaranegara di dunia juga tentu tidak lepas dari aktivitas perdagangan dengan negara lain, akan tetapi tiap negara memiliki komoditas atau barang dagangan utama untuk diperdagangkan kepada negara lain, sebab setiap negara memiliki sumber daya alam yang berbeda-beda dan yang tak dimiliki oleh negara lain. Jika suatu negara tidak memiliki bahan utama untuk dijadikan suatu produk yang dibutuhkan masyarakat tetapi dimiliki oleh negara lain, maka negara tersebut akan melakukan perdagangan atau pertukaran bahan utama dengan negara lain sehingga terjadi kegiatan ekspor impor pada setiap negara. Begitu juga dengan negara yang tidak memiliki sumber daya alam (SDA) seperti Singapura, Jepang, Korea Selatan, yang hanya mengandalkan sumber daya manusia (SDM). Negara tersebut juga pasti akan melakukan aktivitas ekspor impor. Jadi, setiap negara pasti akan saling membutuhkan dalam membangun negara khususnya dalam segi ekonomi.

\section{KAJIAN PUSTAKA}

\section{Ekspor}

Ekspor adalah kegiatan menjual produk dari satu negara ke negara lain melewati batas terluar wilayah kepabeanan suatu negara, dengan tujuan mendapatkan devisa yang sangat dibutuhkan negara, menciptakan lapangan kerja bagi pasar tenaga kerja domestik, mendapatkan pemasukan bea keluar dan pajak lainnya, serta menjaga keseimbangan antara arus barang dan arus uang beredar di dalam negeri (Sasono, 2013). Sedangkan menurut Hutabarat (1989) ekspor adalah perdagangan dengan cara mengeluarkan barang dari dalam ke luar wilayah pabean Indonesia dengan memenuhi ketentuan yang berlaku. Ekspor pada mulanya hanya dilakukan oleh perusahaan berbentuk badan hukum yang telah mendapatkan izin dari Departemen Perdagangan. Eksportir adalah pengusaha yang dapat melakukan ekspor, yang telah memiliki SIUP atau izin usaha dari Departemen Teknis/Lembaga Pemerintah NonDepartemen berdasarkan ketentuan yang berlaku. Ekspor adalah kegiatan mengeluarkan barang dari 
daerah pabean (Undang-undang No.17 tahun 2006). Menurut Amir (2008) kegiatan ekspor adalah upaya seorang pengusaha dalam memasarkan suatu barang atau komoditi yang dikuasainya ke negara asing atau bangsa asing, dengan mendapatkan pembayaran dalam valuta (mata uang) asing, dan melakukan hubungan komunitas dan korespondensi dalam bahasa asing pula.

\section{Impor}

Impor merupakan pembelian dan pemasukan barang dari luar ke dalam negeri. Menurut Amir (2008) kegiatan impor adalah upaya seorang pengusaha untuk memenuhi kebutuhannya atas suatu barang yang kurang tersedia di dalam negeri, sehingga terpaksa membelinya dari negara lain, serta membayarnya dengan valuta asing. Impor adalah proses transportasi barang atau komoditas dari suatu negara ke negara lain secara legal, umumnya dalam proses perdagangan. Proses impor umumnya adalah tindakan memasukkan barang atau komoditas dari negara lain ke dalam negeri. Impor barang secara besar umumnya membutuhkan campur tangan dari bea cukai di negara pengirim maupun penerima. Impor adalah bagian penting dari perdagangan internasional. Kegiatan impor dilakukan untuk memenuhi kebutuhan rakyat. Menurut Hutabarat (1989) impor adalah perdagangan dengan cara memasukkan barang dari luar negeri ke dalam wilayah pabean Indonesia dengan memenuhi ketentuan yang berlaku. Sedangkan Importir adalah perusahaan yang melakukan kegiatan perdagangan dengan cara memasukkan barang dari luar negeri ke dalam wilayah pabean Indonesia dengan memenuhi ketentuan yang berlaku. Impor adalah kegiatan memasukan barang kedalam daerah pabean (Undang-undang No.17 tahun 2006). Impor hanya dapat dilakukan oleh perusahaan berbentuk badan hukum yang mendapat izin dari Departemen Perdagangan.

\section{Kurs (Nilai Tukar)}

Nilai tukar adalah harga dimana mata uang asing yang dinyatakan ke dalam mata uang negara asal (Keown, 2010). Sedangkan Valuta asing merupakan mata uang yang dimiliki oleh suatu negara atau penduduknya tetapi mata uang itu bukan dikeluarkan oleh negara itu sendiri. Mata uang tersebut adalah mata uang domestik bagi negara yang mengeluarkannya dan merupakan alat penukar dan pembayarann yang sah dinegara tersebut (Faud, 2005).Kurs valuta asing juga dapat didefinisikan sebagai jumlah uang domestik yang dibutuhkan, yaitu banyaknya rupiah yang dibutuhkan untuk memperoleh satu unit mata uang asing menurut Sukirno dalam Sedyaningrum (2016). Nilai tukar mata uang adalah harga dari mata uang yang harus ditentukan dalam system ekonomi (Anindita, 2008). Exchange rate atau harga valuta asing adalah perbandingan purchasing power masing-masing mata uang negara yang bersangkutan (tingkat inflasi) menurut Sasono (2013). Valuta asing atau sering disebut Kurs (exchange rate) adalah harga dimana penduduk kedua negara saling melakukan perdagangan menurut Mankiw dalam Pinem (2009).

\section{METODE}

Penelitian yang akan dilakukan menggunakan pendekatan penelitian eksplanatori (Explanatory Research), yaitu penelitian yang menjelaskan hubungan kausal antara variabel penelitian dengan pengujian hipotesis. Pengujian atas dugaan sementara atau teori bahwa terdapat hubungan antara Ekspor Impor Nasional dan Kota Batam terhadap Kurs. Pendekatan yang dipakai dalam penelitian ini adalah metode penelitian dengan pendekatan kuantitatif deskriptif yaitu penelitian terhadap objek dengan tujuan untuk menjelaskan secara sistematis, fakta dan cermat mengenai fenomena yang akan diselidiki.

Metode pengumpulan data yang digunakan dalam penelitian ini adalah metode dokumentasi dengan mendapatkan data berupa laporan tahunan dan laporan data Ekspor Impor berkelanjutan yang telah dikeluarkan oleh Badan Pusat Statistik (BPS) dan Badan Pusat Statistik (BPS) Kota Batam Periode 2014-2016. Data tersebut diperoleh melalui situs yang dimiliki oleh BPS, yaitu https://www.bps.go.id untuk data Nasional dan untuk data Kota Batam diperoleh melalui kantor BPS Kota Batam Jl.Raja Ali Kelana Batam Center, Kota Batam.

\section{HASIL DAN PEMBAHASAN}

Metode pengujian dengan menggunakan statistik deskriptif dan statistik inferensial, penulis ingin menguji pengaruh antara variabel bebas terhadap variabel terikat.

Dimana Statistik deskriptif dalam penelitian digunakan untuk menyajikan nilai minimum, nilai maksimum, rata-rata dan standar deviasi untuk setiap variabel yang digunakan. Variabel yang digunakan dalam penelitian antara lain : variabel bebas yaitu ekpor nasional, impor nasional, ekspor Batam dan impor Batam variabel terikat yaitu nilai tukar USD dan nilai tukar SGD.

Sedangkan statistik inferensial meliputi serangkaian pengujian, seperti uji asumsi klasik, dan uji regresi linier berganda.

Dalam penelitian ini penulis memiliki tiga variabel bebas dengan satu variabel terikat yang digambarkan dalam gambar berikut : 


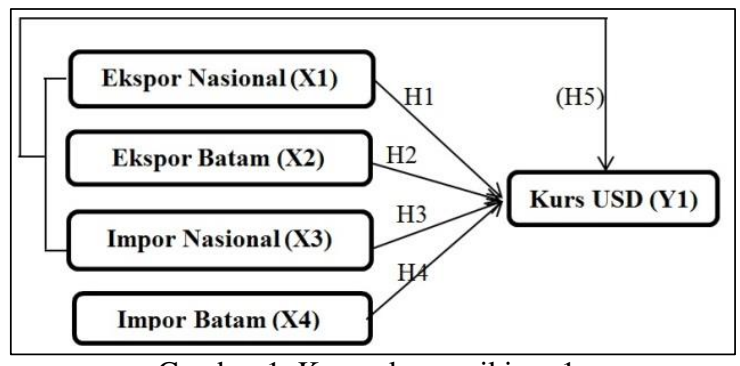

Gambar 1. Kerangka pemikiran 1

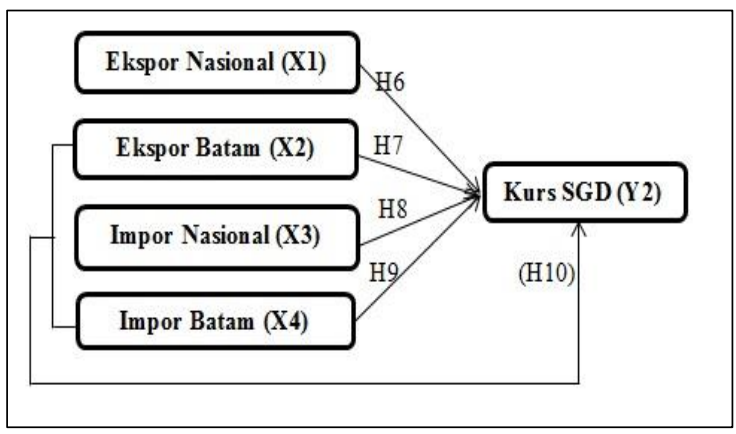

Gambar 2. Kerangka Pemikiran 2

\section{a. Statistik Deskriptif}

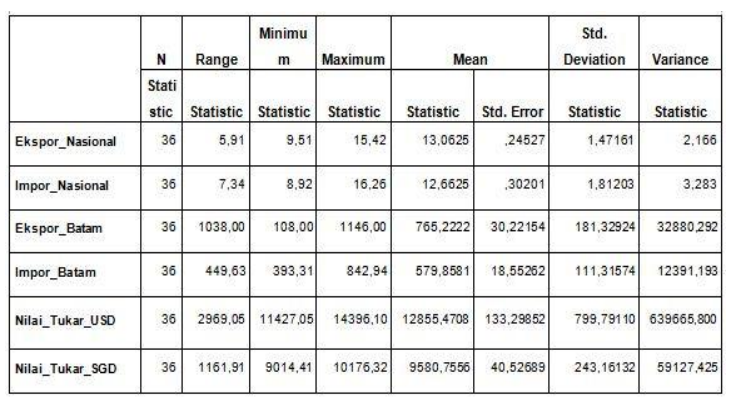

Gambar 3. Statistik Deskriptif

Sumber: Hasil olahan SPSS 2.0

Berdasarkan tabel olah data statistik diatas, diketahui bahwa dari 36 data yang dianalisis didapatkan hasil rata-rata variabel ekspor nasional sebesar 13,07 miliar dalam US\$ dengan nilai tertinggi 15,42 miliar dalam US\$dan nilai terendah 9,51 miliar US\$, serta standar deviasi 1,47 miliar dalam US\$. Untuk variabel impor nasional memiliki rata-rata 12,66 miliar dalam US\$ dengan nilai tertinggi 16,26 miliar dalam US\$ dan terendah 8,92 miliar dalam US\$, serta standar deviasi 1,81 miliar dalam US\$. Untuk variabel ekspor Batam memiliki rata-rata 765,22 Juta dalam US\$ dengan nilai tertinggi 1.146 Juta dalam US\$ dan nilai terendah 108 Juta dalam US\$, serta standar deviasi 181,3 Juta US\$. Sedangkan untuk variabel Impor Batam memiliki rata-rata sebesar 579,85 Juta US\$ dengan nilai tertinggi 842,94 Juta dalam US\$dan terendah 393,31 Juta dalam US\$, serta standar deviasi 111,3 Juta dalam US\$. Untuk variabel nilai tukar USD memiliki nilai rata-rata sebesar 12855 dalam rupiah dengan nilai tertinggi 14396 dalam rupiah dan nilai terendah 11427 dalam rupiah serta standar deviasi dengan nilai 799,79 dalam rupiah. Sedangkan untuk nilai tukar SGD memiliki nilai rata-rata sebesar 9580dalam rupiah dengan nilai tertinggi 10176 dalam rupiah dan nilai terendah 9014 dalam rupiah serta standar deviasi dengan nilai 243,16dalam rupiah.

\section{b. Uji Asumsi Klasik $\mathbf{Y}_{1}$}

1) Uji Normalitas

Uji normalitas dilakukan untuk mengetahui apakah sebuah model regresi, variabel independent, variabel dependent, atau keduanya mempunyai distribusi normal atau tidak. Untuk mengetahuinya digunakan uji Kolmogorov Smirnov, pedoman pengambilan keputusan dalam uji normalitas yaitu bila nilai sig atau signifikan lebih besar daripada 0,01 maka distribusi adalah normalitas (Simetris). Hasil dari pengujian normalitas pada penghitungan uji asumsi klasik Y1 terdapat pada tabel 4.1.1 berikut:

\begin{tabular}{|l|l|}
\hline \multicolumn{1}{|c|}{ Keterangan } & Unstandardized Residual \\
\hline Kolmogorov-Smirnov Z &, 496 \\
Asymp. Sig. (2-tailed) &, 967 \\
\hline \multicolumn{2}{|c|}{ Gambar 4. Uji Normalitas } \\
Sumber: Hasil olahan SPSS 2.0
\end{tabular}

Berdasarkan hasil data yang telah di uji dan tabel diatas maka besarnya nilai kolmogrov-smirnov $Z$ adalah 0,499 dan nilai asymp. Sig. (2-tailed) atau signifikan nya adalah 0,965 , jadi dapat disimpulkan bahwa data residual berdistribusi normal.

\section{2) Uji Multikolinearitas}

Penelitian ini, ada atau tidaknya multikolinearitas dapat diketahui dari koefisien korelasi masingmasing variabel bebas. Jika koefisien korelasi diantara masing-masing variabel bebas lebih besar dari 0,10 maka terjadi multikolinearitas akan tetapi, jika koefisien korelasi diantara masing-masing variabel bebas lebih kecil dari 10 maka tidak terjadi multikolinearitas. Hasil pengujian multikolinearitas untuk penghitungan uji asumsi klasik:

\begin{tabular}{|c|c|c|}
\hline \multirow{2}{*}{ Model } & \multicolumn{2}{|c|}{ Collinearity Statistics } \\
\hline & Tolerance & VIF \\
\hline (Constan & & \\
\hline $\mathrm{x} 1$ & .116 & 8.597 \\
\hline $\mathrm{x} 2$ & .090 & 11.125 \\
\hline $\mathrm{x} 3$ & .767 & 1.304 \\
\hline $\mathrm{x} 4$ & .296 & 3.374 \\
\hline
\end{tabular}

Gambar 5. Uji Mulltikolinearitas

Sumber: Hasil olahan SPSS 2.0

Berdasarakan tabel diatas, diketahui bahwa nilai tolerance ke empat variabel independen lebih dari 0,10 dan nilai VIF kurang dari 10 , maka dapat 
disimpulkan bahwa tidak terjadi multikolinearitas antara variabel bebas.

\section{3) Uji Heteroskedastisitas}

Uji Heteroskedastisitas dilakukan untuk mengetahui apakah dalam sebuah model regresi terjadi ketidaksamaan varians dari residual suatu pengamaatan ke pengamatan lain. Uji heteroskedastisitas dilakukan untuk menguji apakah dalam sebuah model regresi, terjadi ketidaksamaan varians dari residual dari satu pengamatan ke pengamatan yang lain. Jika varians dari residul dari satu pengamatan ke pengamatan yang lain tetap, maka disebut Homokedastisitas. Dan jika varians berbeda, disebut Heteroskedastisitas. Hasil uji heterokedastisitas untuk penghitungan uji asumsi klasik Y1 dapat dilihat pada gambar berikut ini:

\begin{tabular}{|l|c|c|c|c|c|}
\hline \multirow{2}{*}{ Model } & \multicolumn{2}{|l|}{ Unstandardized Coefficients } & $\begin{array}{c}\text { Standardized } \\
\text { Coefficients }\end{array}$ & \multirow{2}{*}{$\mathrm{t}$} & \multirow{2}{*}{ Sig. } \\
\cline { 2 - 5 } & $\mathrm{B}$ & Std. Error & Beta & & \\
\hline (Constant) & 573,830 & 477,977 & & 1,201 &, 239 \\
\hline Ekspor_Nasional & 24,310 & 94,310 &, 125 &, 258 &, 798 \\
\hline Impor_Nasional & $.79,730$ & 87,130 &., 507 &, 915 &, 367 \\
\hline Ekspor_Batam &, 533 &, 298 &, 339 & 1,788 & .084 \\
\hline Impor_Batam &, 111 &, 781 &, 043 &, 142 &, 888 \\
\hline \multicolumn{7}{|c|}{ Gambar 6. Uji Heteroskedastisitas } \\
\hline
\end{tabular}

Berdasarkan uji heteroskedastisitas dengan metode glesjer diperoleh nilai $t_{\text {hitung }}$ pada variabel ekspor nasional sebesar 0,258, impor nasional sebesar ,915 dan impor sebsar 0,142, lebih kecil dari tabel yaitu sebesar 1,688. Sementara itu variabel ekspor Batam dengan nilai $t_{\text {hitung }}$ Sebesar 1,788 lebih besar dari pada $t_{\text {tabel }}$ yaitu sebesar 1,688 , itu berarti variabel $\mathrm{X} 1, \quad \mathrm{X} 2$, dan $\mathrm{X} 4$ tidak terjadi heteroskedastisitas, dan variabel X3 terjadi heteroskedastisitas.

\section{c. Uji Asumsi Klasik $\mathbf{Y}_{2}$}

1) Uji Normalitas

Uji normalitas dilakukan untuk mengetahui apakah sebuah model regresi, variabel independent, variabel dependent, atau keduanya mempunyai distribusi normal atau tidak. Untuk mengetahuinya digunakan uji Kolmogorov Smirnov, pedoman pengambilan keputusan dalam uji normalitas yaitu bila nilai sig atau signifikan lebih besar daripada 0,01 maka distribusi adalah normalitas (Simetris).

\begin{tabular}{|l|r|}
\hline \multicolumn{1}{|c|}{ Keterangan } & $\begin{array}{c}\text { Unstandardized } \\
\text { Residual }\end{array}$ \\
\hline Kolmogorov-Smirnov Z &, 680 \\
Asymp. Sig. (2-tailed) &, 744 \\
\hline
\end{tabular}

Gambar 7. Uji Normalitas

Sumber: Hasil olahan SPSS 2.0

Berdasarkan hasil data yang telah di uji dan tabel diatas maka besarnya nilai kolmogrov-smirnov $Z$ adalah 0,680 dan nilai asymp. Sig. (2-tailed) atau signifikan nya adalah 0,744 , jadi dapat disimpulkan bahwa data residual berdistribusi normal.

2) Uji Multikolinearitas

Uji multikolinearitas bertujuan untuk menguji apakah model regresi ditemukan adanya korelasi antar variabel independen lainnya. Penelitian ini, ada atau tidaknya multikolinearitas dapat diketahui dari koefisien korelasi masing-masing variabel bebas. Jika koefisien korelasi diantara masingmasing variabel bebas lebih besar dari 0,10 maka terjadi multikolinearitas akan tetapi, jika koefisien korelasi diantara masing-masing variabel bebas lebih kecil dari 10 maka tidak terjadi multikolinearitas. Hasil pengujian multikolinearitas untuk penghitungan uji asumsi klasik Y1 terdapat pada tabel berikut:

\begin{tabular}{|c|c|c|}
\hline \multirow{2}{*}{ Model } & \multicolumn{2}{|c|}{ Collinearity Statistics } \\
\cline { 2 - 3 } & Tolerance & VIF \\
\hline (Constant) & & 8,597 \\
\hline Ekspor Nasional &, 116 & 11,125 \\
\hline Impor Nasional &, 090 & 1,304 \\
\hline Ekspor Batam &, 767 & 3,374 \\
\hline Impor Batam &, 296 & \\
\hline
\end{tabular}

Gambar 8. Uji Mulltikolinearitas

Berdasarakan tabel 4.2 diatas, diketahui bahwa nilai tolerance ke empat variabel independen lebih dari 0,10 dan nilai VIF kurang dari 10, maka dapat disimpulkan bahwa tidak terjadi multikolinearitas antara variabel bebas.

3) Uji Heteroskedastisitas

Uji Heteroskedastisitas dilakukan untuk mengetahui apakah dalam sebuah model regresi terjadi ketidaksamaan varians dari residual suatu pengamaatan ke pengamatan lain. Uji heteroskedastisitas dilakukan untuk menguji apakah dalam sebuah model regresi, terjadi ketidaksamaan varians dari residual dari satu pengamatan ke pengamatan yang lain. Jika varians dari residul dari satu pengamatan ke pengamatan yang lain tetap, maka disebut Homokedastisitas. Dan jika varians berbeda, disebut Heteroskedastisitas. Hasil uji heterokedastisitas untuk penghitungan uji asumsi klasik Y2 dapat dilihat pada gambar berikut ini:

\begin{tabular}{|l|r|c|c|c|c|}
\hline \multirow{2}{*}{ Model } & \multicolumn{2}{|c|}{$\begin{array}{c}\text { Unstandardized } \\
\text { Coefficients }\end{array}$} & $\begin{array}{c}\text { Standardized } \\
\text { Coefficients }\end{array}$ & \multirow{2}{*}{$\mathrm{t}$} & \multirow{2}{*}{ Sig. } \\
\cline { 2 - 4 } & \multicolumn{1}{|c|}{$\mathrm{S}$} & Std.Error & Bets & & \\
\hline (Constant) & $-11,723$ & 183,458 & & -.064 & .949 \\
\hline Ekspor_Nasional & 33,638 & 36,198 & .464 & .929 & .360 \\
\hline Impor_Nasionsl & $-23,652$ & 33,443 & -.401 & -.707 & .485 \\
\hline Ekspor_Bstam & .193 & .114 & .329 & 1.691 & .101 \\
\hline Impor_Batam & -.211 & .300 & -.219 & -.702 & .488 \\
\hline
\end{tabular}

Gambar 9. Uji Heteroskedastisitas

Sumber: Hasil olahan SPSS 2.0 
Berdasarkan uji heteroskedastisitas dengan metode glesjer diperoleh nilai $t_{\text {hitung }}$ pada variabel ekspor nasional yaitu sebesar 0,929 , impor nasional sebesar -,707 dan impor Batam sebesar -,702 lebih kecil dari $\mathrm{t}_{\text {tabel }}$ yaitu sebesar 1,688, sementara itu variabel ekspor Batam dengan nilai thitung sebesar 1,691 lebih besar dari pada $t_{\text {tabel }}$ yaitu sebesar 1,688 , itu berarti variabel X1, X2, dan X4 tidak terjadi heteroskedastisitas, dan variabel X3 terjadi heteroskedastisitas.

\section{Uji analisis regresi berganda}

Adapun bentuk model persamaan regresi yang dapat dituliskan dalam persamaan regresi sebagai berikut:

$$
\mathrm{Y}_{1}=36236049.633+(-525124.969) \mathrm{X}_{1}+(-526.958) \mathrm{X}_{2}+(-525124.969) \mathrm{X}_{3}+(-526.958) \mathrm{X}_{4}
$$

$$
\mathrm{Y}_{2}=21972315.414+(-203689.624) \mathrm{X}_{1}+105.997 \mathrm{X}_{2}+(-264.640) \mathrm{X}_{3}+347.010 \mathrm{X}_{4}
$$

\section{Uji t}

Uji ini digunakan untuk mengetahui apakah masing-masing variabel bebasnya secara sendirisendiri berpengaruh secara signifikan terhadap variabel terikatnya. Dengan rumus hipotesis sebagai berikut: Ha: $\mathrm{i} \neq 0$, artinya variabel bebas secara parsial mempunyai pengaruh signifikan terhadap variabel tidak bebas. Ho: $\mathrm{i}=0$, artinya variable bebas secara parsial tidak mempunyai pengaruh signifikan terhadap variabel tidak bebas. $\mathrm{t}$ hitung $>\mathrm{t}$ tabel atau probabilitas kesalahan kurang dari $1 \%$ maka membuktikan variabel bebas secara parsial berpengaruh signifikan terhadap variabel tidak bebasnya, Ha diterima dan Ho ditolak.

Uji f

Uji ini digunakan untuk mengetahui apakah masing-masing variabel bebasnya secara sendirisendiri berpengaruh secara signifikan terhadap variabel terikatnya. Dengan rumus hipotesis sebagai berikut: Ha: $\mathrm{i} \neq 0$, artinya variabel bebas secara parsial mempunyai pengaruh signifikan terhadap variabel tidak bebas. Ho: $\mathrm{i}=0$, artinya variable bebas secara parsial tidak mempunyai pengaruh signifikan terhadap variabel tidak bebas. $\mathrm{t}$ hitung $>\mathrm{t}$ tabel atau probabilitas kesalahan kurang dari $1 \%$ maka membuktikan variabel bebas secara parsial berpengaruh signifikan terhadap variabel tidak bebasnya, Ha diterima dan Ho ditolak.

\section{Pengujian Hipotesis}

Pengujian hipotesis pada penelitian ini menggunakan analisis regresi berganda, uji parsial dan uji simultan. Analisis regresi berganda digunakan untuk mengetahui hubungan antara variabel independen dan variabel dependen. Uji parsial digunakan untuk menguji signifikan hubungan antara variabel $\mathrm{X}$ dan $\mathrm{Y}$, apakah variabel $\mathrm{X}$ benar-benar berpengaruh terhadap variabel $\mathrm{Y}$ secara terpisah atau parsial. Sedangkan uji simultan digunakan untuk mengetahui tingkat apakah ekspor dan impor berpengaruh secara bersama-sama (Simultan) terhadap nilai tukar.

\section{Hipotesis 1}

Berdasarkan hasil uji t untuk variabel ekspor nasional diperoleh $\mathrm{t}$ hitung sebesar $-0,386$. Hipotesis Ha menyatakan bahwa terdapat pengaruh yang signifikan antara ekspor nasional terhadap nilai tukar USD. Setelah dilakukan pengujian dengan menggunakan uji t, hasil uji statistik diperoleh nilai $\mathrm{t}$ untuk variabel ekspor nasional (X1) adalah sebesar $t_{\text {hitung }}-386<t_{\text {tabel }} 1.688$ dan tingkat signifikansi sebesar 0,702 >0,01. Dengan nilai $\mathrm{t}$ hitung yang lebih kecil dari t tabel dan nilai signifikan dibawah 0,01 menunjukkan Ho diterima dan $\mathrm{Ha}$ diterima. Sehingga dapat disimpulkan bahwa terdapat pengaruh negatif dan signifikan antara variabel ekspor nasional terhadap nilai tukar USD.

\section{Hipotesis 2}

Berdasarkan hasil uji t untuk variabel impor nasional diperoleh $\mathrm{t}$ hitung sebesar $-1,417$. Hipotesis Ha menyatakan bahwa terdapat pengaruh yang tidak signifikan antara impor nasional terhadap nilai tukar USD. Setelah dilakukan pengujian dengan menggunakan uji t, hasil uji statistik diperoleh nilai $\mathrm{t}$ untuk variabel impor nasional (X2) adalah sebesar thitung-1,417< $\mathrm{t}_{\text {tabel }}$ 1.688 dan tingkat signifikansi sebesar $0,166>0,01$. Dengan nilai t hitung yang lebih kecil dari t tabel dan nilai signifikan diatas 0,01 menunjukkan Ho diterima dan $\mathrm{Ha}$ diterima. Sehingga dapat disimpulkan bahwa terdapat pengaruh negatif dan tidaksignifikan antara variabel impor nasional terhadap nilai tukar USD.

\section{Hipotesis 3}

Berdasarkan hasil uji t untuk variabel ekspor Batam diperoleh $\mathrm{t}$ hitung sebesar -0,411. Hipotesis $\mathrm{Ha}$ menyatakan bahwa terdapat pengaruh yang tidak signifikan antara ekspor Batam terhadap nilai tukar USD. Setelah dilakukan pengujian dengan menggunakan uji t, hasil uji statistik diperoleh nilai t untuk variabel ekspor Batam (X3) adalah sebesar thitung-,411< $\mathrm{t}_{\text {tabel }} 1.688$ dan tingkat signifikansi sebesar $0,648>0,01$. Dengan nilai t hitung yang lebih kecil dari t tabel dan nilai signifikan diatas 0,01 menunjukkan Ho diterima dan Ha diterima. Sehingga dapat disimpulkan bahwa terdapat pengaruh negatif dan tidak signifikan antara variabel ekspor nasional terhadap nilai tukar USD.

\section{Hipotesis 4}

Berdasarkan hasil uji t untuk variabel impor Batam diperoleh $\mathrm{t}$ hitung sebesar -1,214. Hipotesis Ha menyatakan bahwa terdapat pengaruh yang signifikan antara impor Batam terhadap nilai tukar USD. Setelah dilakukan pengujian dengan menggunakan uji t, hasil uji statistik diperoleh nilai t untuk variabel impor Batam (X4) adalah sebesar $t_{\text {hitung }}-1,214<\mathrm{t}_{\text {tabel }} 1.688$ dan tingkat signifikansi 
sebesar 0,234>0,01. Dengan nilai t hitung yang lebih kecil dari t tabel dan nilai signifikan diatas 0,01 menunjukkan Ho diterima dan Ha diterima. Sehingga dapat disimpulkan bahwa terdapat pengaruh negatif dan tidak signifikan antara variabel impor Batam terhadap nilai tukar USD.

\section{Hipotesis 5}

Berdasarkan hasil uji $\mathrm{t}$ untuk variabel ekspor nasional diperoleh $\mathrm{t}$ hitung sebesar $-0,354$. Hipotesis Ha menyatakan bahwa terdapat pengaruh yang signifikan antara ekspor nasional terhadap nilai tukar SGD. Setelah dilakukan pengujian dengan menggunakan uji t, hasil uji statistik diperoleh nilai $\mathrm{t}$ untuk variabel ekspor nasional (X1) adalah sebesar $t_{\text {hitung }^{-}, 354<t_{\text {tabel }} 1.688 \text { dan }}$ tingkat signifikansi sebesar 0,726 >0,01. Dengan nilai t hitung yang lebih kecil dari t tabel dan nilai signifikan diatas 0,01 menunjukkan Ho diterima dan $\mathrm{Ha}$ diterima. Sehingga dapat disimpulkan bahwa terdapat pengaruh negatif dan tidak signifikan antara variabel ekspor nasional terhadap nilai tukar SGD.

\section{Hipotesis 6}

Berdasarkan hasil uji $t$ untuk variabel impor nasional diperoleh $\mathrm{t}$ hitung sebesar -1,343. Hipotesis Ha menyatakan bahwa terdapat pengaruh yang tidak signifikan antara impor nasional terhadap nilai tukar SGD. Setelah dilakukan pengujian dengan menggunakan uji $t$, hasil uji statistik diperoleh nilai $\mathrm{t}$ untuk variabel impor nasional (X2) adalah sebesar $t_{\text {hitung }}-1,343<t_{\text {tabel }}$ 1.688 dan tingkat signifikansi sebesar $0,189>0,01$. Dengan nilai t hitung yang lebih kecil dari t tabel dan nilai signifikan diatas 0,01 menunjukkan Ho diterima dan $\mathrm{Ha}$ diterima. Sehingga dapat disimpulkan bahwa terdapat pengaruh negatif dan tidak signifikan antara variabel impor nasional terhadap nilai tukar SGD.

Hipotesis 7

Berdasarkan hasil uji $t$ untuk variabel ekspor Batam diperoleh t hitung sebesar -0,499. Hipotesis Ha menyatakan bahwa terdapat pengaruh yang tidak signifikan antara ekspor Batam terhadap nilai tukar SGD. Setelah dilakukan pengujian dengan menggunakan uji t, hasil uji statistik diperoleh nilai t untuk variabel ekspor Batam (X3) adalah sebesar $t_{\text {hitung }}-598<t_{\text {tabel }} 1.688$ dan tingkat signifikansi sebesar 0,621>0,01. Dengan nilai t hitung yang lebih kecil dari t tabel dan nilai signifikan diatas 0,01 menunjukkan Ho diterima dan Ha diterima. Sehingga dapat disimpulkan bahwa terdapat pengaruh negatif dan tidak signifikan antara variabel ekspor Batam terhadap nilai tukar SGD.

\section{Hipotesis 8}

Berdasarkan hasil uji t untuk variabel impor Batam diperoleh $\mathrm{t}$ hitung sebesar 0,860. Hipotesis Ha menyatakan bahwa terdapat pengaruh yang tidak signifikan antara impor Batam terhadap nilai tukar SGD. Setelah dilakukan pengujian dengan menggunakan uji t, hasil uji statistik diperoleh nilai t untuk variabel impor Batam (X4) adalah sebesar $t_{\text {hitung }} 329<\mathrm{t}_{\text {tabel }} 1.688$ dan tingkat signifikansi sebesar $0.744>0,01$. Dengan nilai t hitung yang lebih kecil dari t tabel dan nilai signifikan diatas 0,01 menunjukkan Ho diterima dan Ha diterima. Sehingga dapat disimpulkan bahwa terdapat pengaruh negatif dan tidak signifikan antara variabel impor Batam terhadap nilai tukar USD.

\section{Hipotesis 9}

Berdasarkan hasil uji t, Hipotesis Ha menyatakan variabel-variabel bebas ekspor nasional (X1), impor nasional (X2), ekspor Batam (X3), impor Batam (X4) mempunyai pengaruh yang signifikan secara bersama-sama terhadap variabel terikatnya yaitu nilai tukar USD (Y1). setelah dilakukan pengujian dengan menggunakan uji $\mathrm{F}$, berdasarkan uji statistik $F$ menghasilkan nilai $F_{\text {hitung }} 15,830>$

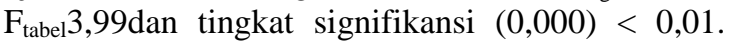
Dengan nilai $\mathrm{F}$ hitung yang lebih besar dari $\mathrm{F}$ tabel dan nilai signifikansi dibawah 0,01 , hal ini menunjukkan Ho diterima dan Ha ditolak berarti hipotesis 9 dinyatakan diterima. Bisa dikatakan secara bersama-sama (simultan) ekspor impor nasional dan Batam berpengaruh positif dan signifikan terhadap nilai tukar USD.

\section{Hipotesis 10}

Berdasarkan hasil uji t, Hipotesis Ha menyatakan variabel-variabel bebas ekspor nasional (X1), impor nasional (X2), ekspor Batam (X3), impor Batam (X4) mempunyai pengaruh yang signifikan secara bersama-sama terhadap variabel terikatnya yaitu nilai tukar SGD (Y2). setelah dilakukan pengujian dengan menggunakan uji $\mathrm{F}$, berdasarkan uji statistik $F$ menghasilkan nilai $F_{\text {hitung }} 5,036>$

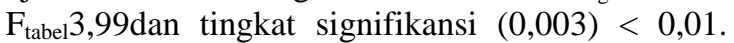
Dengan nilai $\mathrm{F}$ hitung yang lebih besar dari $\mathrm{F}$ tabel dan nilai signifikansi dibawah 0,01, hal ini menunjukkan Ho diterima dan Ha ditolak berarti hipotesis 10 dinyatakan diterima. Bisa dikatakan secara bersama-sama (simultan) ekspor impor nasional dan Batam berpengaruh positif dan signifikan terhadap nilai tukar SGD.

\section{KESIMPULAN DAN SARAN}

\section{Kesimpulan}

Berdasarkan hasil penelitian yang telah dilakukan mengenai analisis ekspor impor terhadap nilai tukar USD dan SGD dapat disimpulkan:

1. Ekspor nasional tidak berpengaruh signifikan terdahap variabel dependen nilai tukar USD.

2. Impor nasional tidak berpengaruh signifikan terhadap variabel dependen nilai tukar USD.

3. Ekspor Batam tidak berpengaruh signifikan terdahap variabel dependen nilai tukar USD.

4. Impor Batam tidak berpengaruh signifikan terhadap variabel dependen nilai tukar USD.

5. Ekspor nasional tidak berpengaruh signifikan terdahap variabel dependen nilai tukar SGD. 
6. Impor nasional tidak berpengaruh signifikan terhadap variabel dependen nilai tukar SGD.

7. Ekspor Batam tidak berpengaruh signifikan terdahap variabel dependen nilai tukar SGD.

8. Impor Batam tidak berpengaruh signifikan terhadap variabel dependen nilai tukar SGD.

9. Ekspor impor nasional dan ekspor impor Batam berpengaruh signifikan terhadap variabel dependen nilai tukar USD.

10. Ekspor impor nasional dan ekspor impor Batam berpengaruh signifikan terhadap variabel dependen nilai tukar SGD.

\section{Saran}

Bagi importer dan pemerintah diharapkan menekan kegiaran impor, lebih memperhatikan jumlah ekspor dan impor agar tetap seimbang, dan tetap mempertahankan angka ekspor. Pemerintah harus meningkatkan ekspor dengan peningkatan kualitas produk yang berstandar internasional sehingga mampu menekan adanya impor, sehingga jumlah impor yang kurang seimbang dengan volume ekspor dapat mendorong apresiasi nilai tukar rupiah terhadap dollar USD dan SGD. Dengan mengetahui informasi mengenai pekembangan variabelvariabel tersebut, eksportir dan importir dapat menentukan kegiatan perdagangan yang harus dilakukan. Bagi eksportir dan importir diharapkan memperhatikan berbagai informasi mengenai perkembangan kurs, mengingat bahwa ke empat variabel tersebut lebih berpengaruh signifikan terhadap nilai tukar Rupiah terhadap dollar USD maupun SGD.

\section{DAFTAR PUSTAKA}

Anindita,R. (2008). Bisnis dan Perdagangan Internasional. Yogyakarta: Andi Offset.

Benny,J. (2014). Ekspor dan Impor Pengaruhnya Terhadap Posisi Cadangan Devisa Di Indonesia. Ekonomi Jurnal, 3-4.

Direktorat Jenderal Bea dan Cukai.2013. http://www.beacukai.go.id/ (Diakses Tanggal 14 Februari 2017).

Faud, Mohd Ramli;. (2005). Akuntansi Perbankan Petunjuk Praktis Operasional Bank. Yogyakarta: Graha Ilmu.

Hutabarat,R. (1989). Ketentuan-ketentuan dan Tata Laksana Transaksi Ekspor-Impor Indonesia. Jakarta: Erlangga.

Indawati, T. (2016). Pengaruh Profitabilitas, Leverage dan Ukuran Perusahaan terhadap Pengungkapan Corporate Social Responsibillity. Skripsi Administrasi Bisnis Terapan. Politeknik Negeri Batam, 52.

Kementerian Hukum dan Hak Asasi Manusia Republik Indonesia.2014 http://www.peraturan.go.id/ $\quad$ (Diakses Tanggal 14 Februari 2017).
Keown, Arthur J. (2005). Manajemen Keuangan: Prinsip dan Penerapan, Edisi Kesepuluh, Jilid 2. Jakarta Pusat: Indeks.

M.S,Amir. (2004). Strategi Memasuki Pasar Ekspor. Jakarta: Victory Jaya Abadi.

M.S,Amir. (2008). Handbook of Export Import Business. Jakarta: Victory Jaya Abadi.

Muzakky, A. (2015). Pengaruh Inflasi, Tingkat Suku Bunga SBI, Pendapatan Per Kapita, dan Ekspor Terhadap Nilai Tukar Rupiah dan Pertumbuhan Ekonomi. Jurnal Administrasi. Jurnal Administrasi Bisnis. Vol. 23 No. 1, pp 8-9.

Pinem,J.R. (2009). Analisis Pengaruh Ekspor, Impor, Kurs Nilai Tukar Rupiah Terhadap Cadangan Devisa Indonesia. Skripsi Ekonomi Pembangunan. Universitas Sumatra Utara,32.

Sasono, H.B. (2013). Manajemen Ekspor dan Perdagangan Internasional. Yogyakarta: Andi Offset.

Sedyaningrum, M, Suhadak. Nuzula, N. F. (2016). Pengaruh Nilai Ekspor, Impor dan Pertumbuhan Ekonomi terhadap Nilai Tukar dan Daya Beli Masyarakat di Indonesia. Jurnal Administrasi Bisnis. Vol. 34 No.1, pp 2-3.

Sugiyono. (2014). Metode Penelitian Kuantitatif Kualitatif dan R\&D. Bandung: Alfabeta.

Thomson, H. (2013). US Cotton Exports and Bilateral Exchange Rates. Agricultural Economics Journal. Vol. 14 No.1, pp 1011.

Ulfa, S. A. (2012). Pengaruh JumlaBegitu puładdengan investasi (JBU), Suku Bunga Sertifikat Bank Indonesia (SBI), Impor, Ekspor Terhadap Kurs Rupiah/Dollar Amerika Serikat Periode Januari 2006 sampai Maret 2010. Economics Development Analysis Journal. Vol. 1 No.1, pp 44.

Yudha, A. E. (2009). Analisis Pengaruh Tingkat Suku Bunga SBI dan Volume Ekspor Impor terhadap Nilai Tukar Rupiah. Jurnal Ekonomi Pembangunan, 4.

Yuliyanti, N. I. (2014). Pengaruh Jumlah Uang Beredar (M2), Tingkat Suku Bunga SBI, Impor, dan Cadangan Devisa terhadap Nilai Tukar Rupiah/ Dollar Amerika Tahun 2001-2013. Economics Development Analysis Journal. EDAJ 3 (2) (2014). ISSN 2252-6765. Universitas Negeri Semarang, pp 8-9. 